\title{
Philosophiques
}

\section{Livres reçus (automne 2007)}

Volume 34, numéro 2, automne 2007

URI : https://id.erudit.org/iderudit/017433ar

DOI : https://doi.org/10.7202/017433ar

Aller au sommaire du numéro

Éditeur(s)

Société de philosophie du Québec

ISSN

0316-2923 (imprimé)

1492-1391 (numérique)

Découvrir la revue

Citer ce document

(2007). Livres reçus (automne 2007). Philosophiques, 34(2), 433-434.

https://doi.org/10.7202/017433ar

Ce document est protégé par la loi sur le droit d'auteur. L'utilisation des services d'Érudit (y compris la reproduction) est assujettie à sa politique d'utilisation que vous pouvez consulter en ligne.

https://apropos.erudit.org/fr/usagers/politique-dutilisation/
Cet article est diffusé et préservé par Érudit.

Érudit est un consortium interuniversitaire sans but lucratif composé de l’Université de Montréal, l'Université Laval et l'Université du Québec à Montréal. Il a pour mission la promotion et la valorisation de la recherche. https://www.erudit.org/fr/ 


\section{Livres reçus (automne 2007)}

Angelelli, Ignacio, Études sur Frege et la philosophie traditionnelle, trad. par J.-F. Courtine,

A. de Libera, J.-B. Rauzy et J. Schmutz, Paris, Vrin (coll. Problèmes et controverses), 2007, 365 p.

Angenot, Marc, Eddi, Maï-Linh, Paule-Monique Vernes, La tolérance est-elle une vertu politique?, Québec, Presses de l’Université Laval (coll. Verbatim), 2006, 70 p.

Billouet, P., J. Gaubert, N. Robinet, et A. Stanguennec, (dir.), L’homme et la réflexion. Actes du XXX $X^{e}$ congrès de l'Association des sociétés de philosophie de langue française, Paris, Vrin, 2006, 512 p.

Clavien, Christine et Catherine El-Bez, (éd.), Morale et évolution biologique: entre déterminisme et liberté, Presses polytechniques et universitaires romandes (coll. anthropos), 2007, $352 \mathrm{p}$.

Courtine, Jean-François, La cause de la phénoménologie, Paris, Presses Universitaires de France (coll. Épiméthée), 2007, 276 p.

De Libera, Alain, Archéologie du sujet. Vol. I, Naissance du sujet, Paris, Vrin (coll. Histoire de la philosophie), 2007, 448 p.

Engel, Pascal, Va savoir! De la connaissance en général, Paris, Hermann, 2007, $256 \mathrm{p}$.

Hintikka, Jaakko, Les principes des mathématiques revisités, Paris, Vrin (coll. Mathesis), 2007, 319 p.

Huglo, Pierre-André, Sartre : questions de méthode, Paris, L'Harmattan (coll. Épistémologie et philosophie des sciences), 2005, 105 p.

Ogien, Ruwen, L'éthique aujourd'hui. Maximalistes et minimalistes, Paris, Gallimard (coll. Folio essais), 2007, 253 p.

Př́onský, Franz, Bolzano contre Kant. Le nouvel anti-Kant, Paris, Vrin (coll. Textes philosophiques), Paris, Vrin, 2006, 185 p.

Seron, Denis, Théorie de la connaissance du point de vue phénoménologique, Liège, Bibliothèque de la Faculté de philosophie et lettres de l'Université de Liège, 2006, 307 p. 
Outre les ouvrages qui apparaissent dans cette liste, la rédaction de Philosophiques peut obtenir, pour fin de compte-rendu ou d'étude critique, la plupart des livres parus récemment.

Les personnes désireuses de faire un compte-rendu ou une étude critique sont priées de s'adresser à :

\author{
Jimmy Plourde \\ Philosophiques \\ Département de philosophie \\ Université du Québec à Montréal \\ c.p. 8888 , succ. Centre-ville, Montréal, Qc \\ H3C 3P8 \\ plourde7@yahoo.com
}

